\title{
Esanland in the Context of Modern Development Planning in Nigeria
}

\author{
Williams Ehizuwa Orukpe \\ Department of History and International Studies, University of Benin, Benin City, Nigeria \\ Telephone: 08030666367; 08026277547,E-mail: Williams.orukpe@uniben.edu
}

KEYWORDS Development Economics. Historiography. Rural. Integration. Nationalism

ABSTRACT This paper examines Esanland in the context of modern development planning in Nigeria. It interrogates the problem of planning without development in Esanland and Nigeria. The paper adopts the qualitative research method to explain the phenomenon of rural underdevelopment obstructing Nigeria's economic development. It finds that, since Nigeria attained independence in 1960, there has been no scarcity of development planning in the country. But there is a stark paradoxical absence of commensurate economic development. This critical review of planning in Nigeria identified economic dysfunctionalism, resources diffusionism and ethnic politics as the bane of plan implementation and rural development. Therefore, using the economy of Esanland as a case study, this paper engages with how these factors interface to undermine and disconnect rural economies. It concludes that rural economic development-oriented planning and dispassionate implementation of plans are developmental imperatives for pre-empting development planning in Nigeria from being a waste of time.

\section{INTRODUCTION}

By 2020, Nigeria will have a large, strong diversified, sustainable and competitive economy that effectively harnesses the talents and energies of her people; and responsibly exploit her natural endowments to guarantee a high standard of living and quality of life to her citizens (National Planning Commission 2009).

The problem of economic development in Nigeria has engaged the attention of scholars from diverse disciplines. Dibua (2013), Kolawole and Ojapinwa (2013), Akinbowale (2018), Uche (2019), and Admos et al. (2019) interrogated this problem. Nigeria's plague of economic backwardness and underdevelopment is a severe sneer to the African giant. Since 1960, relentless efforts have been made to reverse the economic misfortunes of Nigeria and assert her economic sovereignty. This drive birthed several development plans, policy programmes, and visions such as the one quoted above. Despite all the well-intended efforts to recalibrate and reposition the economy of Nigeria on a path of greatness, economic development in the nation has remained an illusion (Ministry of Budget and National Planning 2017). The inability of Nigeria to harness and exploit her abundant human and natural resources for development is directly responsible for her underdevelopment, and the rise of development economics history in Nigeria. Development economics history is a branch of economic history poised to interrogate and explain the obstacles to economic development in Nigeria and other Less Developed Countries (LDCs). It highlights how the application of economic principles can help salvage underdeveloped societies. To this end, development economics promotes development planning as the foremost economic principles to combat economic backwardness and underdevelopment, and then capital formulation (through savings and investment), economic diversification, product and price stabilisation, and the control of foreign exchange rates (Todaro and Smith 2011).

Economic Development Planning (EDP) in Nigeria since 1960 ranges from fixed-medium term to perspective plans. It started with the First National Development Plan in 1962 to the current Vision 20:2020 that seeks to place Nigeria among the top 20 world best economies by the year 2020 . However, it is instructive to note that economic development planning is not a spontaneous phenomenon (Akinbowale 2018). The historicism of planning is traceable to Smith's (2003) "The Wealth of Nations", in which he investigated the causation behind economic development disparity among nations in the 18 century. He identified planning through the deliberate application of the division of labour in industrial production as the bastion of British economic development. Since Smith's first writing in 1776, planning has become a worldwide development necessity. Today, the problem of economic underdevelopment, especially in Africa and Asia, has drawn diverse scholars (Hodder 1972; Rodney 1972; Jhingan 1997; Todaro and Smith 2011; Acemoglu and 
Robinson 2013) to this field of enquiry. Their quest is to problematise underdevelopment and proffer viable solutions to it. Huertas-Ramos (2017) traced modern planning as a management tool to Joseph's Stalin's Five-Year Plan, 19281932. India in 1933 adopted a White Paper that led to the initiation of the Bombay Plan in 1944. In 1933 and 1939, the United States of America (USA) initiated the New Deal, and Marshall Plan in 1948 to fast track post-World War II economic recovery of Western Europe. The Cold War (19451991) deployment of planning entrenched it into modern statecraft and attracted diverse scholars to development economics.

The Cold War brought to the front burners of economic discourse the problem of economic underdevelopment and demonstrated its impact on national and international peace and security. Thus, researchers have become increasingly interested in development economics fired by the desire to provide a veritable intellectual framework that will help bridge the economic development gap among nations. During the Cold War, the economic development of the Third World Countries (TWCs) was conceived to be the surest way to help them resist the overtures of the U.S.A. and the Union of Soviet Socialist Republics (USSR) and forestall the loss of their political and economic sovereignty to them (Jhingan 1997). Hence, the United Nations (2020) identified financial fragility, soaring debt, weak productive investments, low productivity of labour and overdependence on commodities as development obstacles that developing economies must tackle. Thus, since Nigeria's attainment of independence, economic scholars are of the view that her economic sovereignty and the welfare and happiness of her citizens, depends on the economic development of the nation.

Therefore, it is against this backdrop that this paper will critically review Nigeria's developmental efforts through planning and the constraints experienced since 1960 . The focus of this paper is to interrogate and explain why development planning has not translated into economic development in Nigeria, despite her potentials for growth and development. According to Hodder (1972: 226), since independence, all tropical nations have initiated one form of the national economic development plan or the other. Admos et al. (2019) write that at independence, most of these countries conceived having a national development plan as a symbol of national sovereignty. It demonstrates that development planning in Nigeria has never been the problem, but the lack of coordination and harmonisation of the plan by the government (Akinbowale 2018). Hence, this paper will use the neglect of rural economies in plan implementation in Nigeria to highlight this lack of coordination and harmony. It will establish the fact that national economic development plans in post-colonial Nigeria have only been national in nomenclature and not in their implementation. By demonstrating that, the performance of economic development plans in Nigeria is grossly lopsided in favour of urban areas.

Although Nigeria has 774 Local Government Areas (LGA) or Local Economic Units (LCU), this paper will use Esanland that comprises five LGAs or LCUs, as its case study. The study area is located in the south-south geopolitical zone of Nigeria, and precisely in the forest region economic zone of Edo State, created in 1991. The thirty-five (35) autonomous communities of Esanland namely, Uromi, Irrua, Ekpoma, Ekpon, Emu, Ewohimi, Ewatto, Ewu, Ubiaja, Egoro, Ebelle, Ewosa, Ukhun, Amahor, Ugbegun, Igueben, Idoa, Ohordua, Okhuesan, Oria, Ogwa, Okalo, Uzea, Onogholo, Orowa, Urohi, Ugun, Udo, Ujiogba, Iyenlen, Ifeku, Ilushi, Opoji, Ugboha and Uroh, collectively constitute one of Nigeria's rural economies. This rural economy is divided into five economic units, namely Esan West, Esan South-East, Esan NorthEast, Esan Central, and Igueben. Therefore, the kernel of this development economics historiography is that the economic development of Nigeria depends on the even development and integration of these economy units and others elsewhere in the modern Nigerian economy.

\section{Objectives of the Paper}

The main objective of this paper is to examine the problem of economic development through planning in Nigeria. It also interrogates the issue and impact of rural underdevelopment on the Nigerian economy. The paper further highlights the economic potential and capacities of Esanland as a representative of other rural economies in Nigeria to contribute to the economic development of the country. It is along this line that the paper is designed to investigate the political economy of planning in Nigeria. It will establish that the dysfunctional implementation of plans

J Economics, 11(1-2): 1-16 (2020) 
is responsible for rural economic neglect, and the broad economic development gulf between rural and urban economies in Nigeria. More so, the paper demonstrates that the continued neglect and underdevelopment of rural economies constitute severe economy wastage and leakages adversely affecting Nigeria's Gross Domestic Product (G.D.P.), National Income (N.I.) and Per Capita Income.

\section{METHODOLOGY}

The research methodology employed in this paper is the historical research method. But because there are over 250 ethnic groups in Nigeria, the report is anchored on the case study research design. It adopts Esanland as its study area and a representation of all neglected and marginalised rural areas in Nigeria, because they all suffer the same misfortune. Being a descriptive research, the discussion, analysis, explanation and presentation of facts in this paper are based on the qualitative method, and supported with the use of tables. The data used in this paper are both primary and secondary materials. The primary materials include oral evidence sourced through unstructured interviews, archival materials and reports, while the secondary materials mainly include books and journal articles. For objectivity, data were scrutinised and reviewed through deductive and inference reasoning, and materials were cross-referenced and corroborated. In writing the report, the researcher utilised the American Psychology Association's (APA) in-text method of citation and referencing, and the political economy analysis framework.

\section{RESULTS}

The paper finds that national development planning in Nigeria since 1960 is only national in nomenclature, but not in implementation. These are evident in the partial implementation of development plans, visions, policies and programmes directly responsible for the overconcentration of economic institutions and infrastructures in the elitist urban centres of Nigeria. The paper also finds that ethnic and oil politics are political economy factors fuelling economic neglect and underdevelopment in Esanland and other rural areas in Nigeria. Hence, it maintains that there is nothing wrong with the development plans conceived in Nigeria since independence. But the massive politicisation of the economy and plan implementation process is the problem. These are demonstrable in the politicisation of economic decisions such as the location of industries, road construction and provision of social amenities in Nigeria. The resultant economic inequality has increased the incidence of extreme poverty in rural areas than in urban areas.

Table 1: Poverty and inequality indices in Nigeria, 2019

\begin{tabular}{lccc}
\hline State/Section & $\begin{array}{c}\text { Poverty } \\
\text { headcount } \\
\text { rate }\end{array}$ & Poverty index & $\begin{array}{c}\text { Squared } \\
\text { poverty index } \\
\text { (extreme) }\end{array}$ \\
\hline Urban & 18.04 & 4.47 & 1.68 \\
Rural & 52.10 & 17.42 & 7.78 \\
Edo & 11.99 & 2.90 & 1.01 \\
\hline
\end{tabular}

Source: Adapted from National Bureau of Statistics

(NBS), 2019 Poverty and Inequality: Executive Summary, May 2020.

Table 1 shows the poverty gulf between urban and rural areas in Nigeria. The 2019 rural poverty index of 17.42 percent compared to urban poverty index of 4.4 percent proves that implementation of development planning in Nigeria has been skewed. Edo state's poverty headcount of 11.9 percent shows that the people of Esanland and other rural areas in the country have very low per capita income per household. Consequently, this paper contends that rural economic exclusionism in plan implementation, beyond accentuating rural poverty constitutes a severe impediment to Nigeria's economic development. It is because of the economic wastages and leakages in the modern Nigerian economy it engenders. Indeed, rural areas are the raw materials and resources home base of Nigeria, and therefore, the paper finds that the continued disconnection and poor harnessing of Esan economic potentials contribute significantly to economic development eluding the country. It also finds that rural development is germane for curbing and perhaps, the eradication of the diverse levels of poverty perturbing the people of Esanland and other rural areas in Nigeria, be it absolute poverty, relative poverty or dollar per day poverty. Hence, it maintained that rural development is the key to the overall economic development of Nigeria.

Table 2 shows that the different types of poverty plaguing Nigerians are higher in rural areas than

J Economics, 11(1-2): 1-16 (2020) 
Table 2: Poverty breakdown in Nigeria, 2010

\begin{tabular}{lcccc}
\hline $\begin{array}{c}\text { State/Sec- } \\
\text { tion }\end{array}$ & $\begin{array}{c}\text { Food } \\
\text { poverty }\end{array}$ & $\begin{array}{c}\text { Absolute } \\
\text { poverty }\end{array}$ & $\begin{array}{c}\text { Relative } \\
\text { poverty }\end{array}$ & $\begin{array}{c}\text { Dollar per } \\
\text { day poverty }\end{array}$ \\
\hline Urban & 26.7 & 52.0 & 61.8 & 52.4 \\
Rural & 48.3 & 66.1 & 73.2 & 66.3 \\
Edo & 39.4 & 65.6 & 72.5 & 66.0
\end{tabular}

Source: Adapted from National Bureau of Statistics, Nigeria Poverty Profile 2010, January 2012.

urban. The apparent reason for this discrepancy is the overconcentration of development indices such as infrastructure and industries in urban centres. These have helped to create more employment opportunities, increased per capita income and improved standard of living in an urban metropolis. The 66.3 percent of people living on less than USD 1 per day in the rural area shows that more of Nigeria's population lives in such areas. Hence, the refocusing of government's development efforts in rural areas is the key to ending the endemic poverty plaguing Nigeria.

\section{DISCUSSION}

\section{Understanding Economic Development and Development Planning}

In development economics, development planning reflects in an excellent living standard of people. Thus, development planning is regarded to be the absolute path taken by societies such as the U.S.A., China, Russia, Britain, Japan and Germany, among others to attain their current level of economic development. Hence, Uche (2019) maintained that planning is the surest path to Nigeria's economic prosperity, recovery and optimal performance. However, Hodder (1972) warns that having an economic development plan does not automatically translate into economic development. Hence, for a better comprehension of the nexus between development planning and economic development, it is appropriate for this paper to attempt a conceptual explanation of the distinction between economic growth and economic development, and their relatedness with development planning. According to Huertas-Ramos (2017), abstract modification of planning is not only crucial for configuring planning techniques, but also for understanding why plans fail.

Economic Development Planning in all societies is the soul of economic growth and development. Akinbowale (2018) explains that development planning is necessary to safeguard independence. But does economic growth automatically translate into economic development?

There is a growing tendency among scholars, to use economic growth and development interchangeably (Awopegba 2003), but they mean different things in development economics. Madison views economic growth as the rise in income levels in a developed and wealthy country and regards the general increase in income level in underdeveloped and emerging countries as economic development (cited in Jhingan 1997). From his perspective, it can be unfair that economic growth is a phenomenon that can only be experienced in developed societies, and that a nation can experience economic growth only after first achieving economic development. Contrary to Madison's view, Hicks explains that both underdeveloped and developed countries can experience economic development. He writes that, in an underdeveloped society, economic growth is when a nation learns to mobilise unused resources with well-known uses for action. In developed societies, economic development is when a country improves its capacity to exploit resources it already knows how to control (cited in Jhingan 1997).

For Schumpeter, economic development is the discontinuous and spontaneous change in the stationary state of an economy, which forever displaces the previous equilibrium state. Economic growth is a gradual and steady long term economic change brought about by a gradual increase in savings and population (cited in Jhingan 1997). While Kindleberger adds that, economic growth means an increase in output, and that economic development is an increase in production and changes in the technical and institutional arrangement by which work is produced and distributed (cited in Jhingan 1997). Consequently, Jhingan (1997) explains that economic growth is the sustained quantitative increase in a country's per-capita output or income accompanied by an expansion in its labour force, consumption, capital and volume of trade. Economic development is economic growth plus change, that is, the qualitative changes in the economy's wants, goods, incentives, institutions, productivity, and knowledge, or the upward movement of the entire social system of a nation. Along this line, Awopegba (2003) adds that economic growth refers to the increase in an economy's output and services over time,

J Economics, 11(1-2): 1-16 (2020) 
and economic development is a state whereby a higher percentage of the population progressively benefits from a nation's economic growth over time. Therefore, the Welsh Government (2013) maintained that economic development is the development of land and capital into activities that generate wealth, jobs and income for the people.

Todaro and Smith (2011) observe that economic development is a multidimensional process involving significant changes in social structures, popular attitudes, national institutions, as well as the acceleration of economic growth, reduction of inequality and the eradication of poverty. In a related dimension, Walter Rodney argues that economic development has many side processes. At individual level it implies increased skill and capacity, greater freedom, creativity, self-discipline, responsibility and material well-being. For the economy, the level is attained when members of the society jointly increase their capacity for dealing with their environmental challenges. Therefore, economic development in a nation cannot be measured by an increase in the Gross Domestic Product (GDP) alone. As was hitherto the case, but by the Gross National Product (GNP) (Real National Income (RNI)), GNP Per Capita, the welfare of citizens, and other social indicators like health, education, food, water, sanitation, and housing among others.

Although development economics scholars differ on the conceptual meaning of economic growth and development, they unanimously agree that proper economy planning and plan implementation are crucial to economic development. But they are again divided on the meaning of economic planning as a tool of development. Hence, the pertinent need for the researcher to interrogate the concept of economic planning here. Economic planning, as Jhingan (1997: 488) puts it, is a technique, a means of realising a pre-determined end, aims and objectives, laid down by central planning authority. Lordwin defines economic planning as a scheme of financial organisation in which individual and separate plants, enterprises, industries acted as coordinate units of one single system to utilise available resources to achieve maximum satisfaction of the people's needs within a given time (cited in Jhingan 1997).

Consequently, Ferdynand Zweig argues that economic planning is not mere planning of towns, public works or a separate section of the national economy, but of the national economy as a whole (cited in Jhingan 1997). Therefore, for economic planning to be able to cover the needs of all the component units of a nation, Dickinson maintains that the planning authority must base its planning on a comprehensive survey of the economic system as a whole (cited in Jhingan 1997). Hence, Hodder (1972: 226-227) asserts that a well-formulated economic development plan is a comprehensive one. It is based on a complete assessment of a country's economic life and problems not as individual strands or projects but as part of the whole. According to Dibua (2013: 1), comprehensive planning and economic development policies have failed in Nigeria due to corruption. He identified the corrupt practices frustrating planning and derailing economic development as clientelism, godfatherism, prebendalism, patrimonialism and neopatrimonialism, among others (Dibua 2013: 2).

Nonetheless, Jhingan (1997) insists that comprehensive economic planning is indispensable for eradicating poverty, raising national and per capita income, reducing inequalities in income and wealth. It is pertinent for increasing employment opportunities and for promoting rapid allround economic development if dispassionately implemented. Consequently, for this paper, the researcher defines economic planning as the meticulous and dispassionate process of harvesting the economic problems of a nation into a centrally administered policy document for the common good of all. These are crucial to the economic growth of the modern Nigerian economy, which the researcher defines as the sustainable increase in the economic institutions, and the goods and services produced in Nigeria at a given period. The nation's economic growth is the precursor of its economic development. Therefore, this paper views economic development in Nigeria as a situation whereby the increase in the modern Nigerian economy translates into a low cost of living and a high standard of living. Put differently, economic development is when growth in the Nigerian economy is enough to equitably accommodate and satisfy the needs and aspirations of all Nigerians and bring them happiness. But for a better grasp of Nigeria's current economic underdevelopment, it is apropos for this paper to interrogate the structure and dysfunctionalism of the modern Nigerian economy.

J Economics, 11(1-2): 1-16 (2020) 
Structure and Dysfunctionalism of the Modern Nigerian Economy

The structure of the modern Nigerian economy since 1960 is evolutionary (Iyoha 2003). In the $21^{\text {st }}$ century, it has remained so vacillating and daggling between agriculture, manufacturing, and crude oil exportation. But in terms of its composition, the modern economy of Nigeria is 'dualistic'. It composed of an urban (macro) economy and a rural (micro) economy that is underdeveloped and disconnected. This is partly responsible for the underdevelopment and dysfunctionality of the Nigerian economy. The modern Nigerian economy is mostly an agricultural economy, with approximately seventy-three percent of the country's labour force actively engaged in the production of primary agricultural products. The resultant effect of this on Nigeria's economic development is that it had reduced the nation's economy into a monocrop, import-dependent, and an underdeveloped economy lacking genuine industrial foundation (Uwubanmwen 2003: 3-4).

Jhingan (1997) in his observation found less developed economies to be with high population growth, general poverty, natural resources, monoeconomy, unemployment, insufficient capital, lack of enterprise, and dualistic economy, which are the obstacles to their economic development and the reason they are poor. As an underdeveloped and dysfunctional economy, the bleak financial fortune of the modern Nigerian economy worsened by the neglect of its rural economies. While the urban economies of Nigeria located in significant towns are fully developed market economies, the rural economies of Nigeria found in rural villages since 1960 has remained subsistent and disconnected. Iyoha (2003: 4) writes that while the urban economy is a small, modern, monetised and formal economy, and the rural economy is a largely unorganised and informal economy, they are yet to be fully monetised because of the overconcentration of banks in urban areas.

On Nigeria's economic dysfunctionalism, Lloyd (1974) in his "Power and Independence: Urban African's Perception of Social Inequality" maintained that economic development in Nigeria does not benefit all areas equally. This development disparity created several leakages and wastages in the Nigerian economy, which Nigeria's Economic Recovery and Growth Plan was initiated to end by
2020 (Ministry of Budget and National Planning 2017: 10). For now, while the features of economic development and affluence are preponderant in the urban areas, the rural areas have remained mostly unchanged. The rural economy is the direct opposite of the urban economy. The rural area is often referred to as countryside because of the lack of essential infrastructural development (Chukwuemeka et al. 2013). According to Basumatary (1993: 1842), access to government services, hospital, educational institutions, drinking water, street lighting, and electricity is limited in rural areas. These conditions in Nigeria have made poverty to be more predominant in the rural areas of the country compared to the urban areas (Awojobi 2014). The rural-urban poverty gulf in Nigeria has continued to increase yearly because of the economic neglect of the rural regions.

Therefore, due to Nigeria's rural-urban economic development dichotomy and disintegration, Adedeji (1981) maintained that the overall economic performance of Nigeria, like other sub-Sahara African economies since 1960, has continued to be unsatisfactory. The consequence of this dysfunctionality is that sixty years after independence, the structure of the Nigerian economy still bears the unmistakable mark of colonialism. Because despite the undeniable evidence of modernity evident in the presence of import-substitution industries, the modern Nigerian economy is still import-oriented, a raw material producing economy and a dumping ground for foreign manufactured finished goods (Adedeji 1981: 25). Further, commenting on the impact of economic dysfunctionalism in less developed economies, Donaldson (1971) observed that economic dualism had produced a modern sector economy grafted onto a traditional economy. They are separated, by as wide as the divide between the rich and poor, marred by the absence of egalitarian ideals and social justice.

These imply that urban and rural economies are configured differently. The urban economy, on the one hand, is mechanised and digital, employing the latest capital-intensive method in the production of goods and services; while the rural economy on the other hand, is manual and depends on primitive tools and handicraft (labour intensive) methods of production (Donaldson 1971: 50-51). Understandably, Ezeife (1981: 182) concluded that there is a disparity in the balance of businesses between the rural and urban economies. These are because most

J Economics, 11(1-2): 1-16 (2020) 
formal enterprises and government establishments are in urban areas; and they are structurally and operationally different from rural businesses. More so, providing insight into the causation of economic dysfunctionalism in less developed economies, Acemoglu and Robinson (2013: 68) write that, "Poor countries are poor because those who have power make choices that create poverty. They get it wrong not by mistake or ignorance but on purpose."

Consequently, Donaldson posits that developing economies have remained the hewers of wood and drawers of water for the global economy, because of the lack of favourable rural policies that will prevent the release of labour in rural areas, for absorption in the urban industry, and absence of policies directed at creating employment opportunities in rural areas (Donaldson 1971: 106-107). Put simply, less developed economies like the modern Nigeria economy have remained underdeveloped due to disconnection of rural economies in the country. Therefore, to demonstrate this economic problem in post-colonial Nigeria, this paper will now critically review the extent to which Esanland like other rural areas is side-lined in plan implementation. It will highlight the neglect of Esan economy in the performance of Nigeria's fixed medium-term and perspective plans, visions, policies and programmes since 1960.

\section{Esanland and the First and Second National Development Planning, 1962-1974}

The economic underdevelopment of Nigeria caused by the vast development gap between urban and rural economies is a colonial heritage. Its existence is mainly the consequence of the diffusionist model of development the British used to administer the country. At independence, economic development planning was promptly resorted to by the leadership of Nigeria to bridge the development gap between rural and urban economies, and fast track the overall economic development of the nation. In West Africa, Hopkins (1973) traced the economic inequality between rural and urban economies beyond the colonial era. He writes that the financial discrepancy between the rural and urban economies in the pre-colonial era was evident in the functions they served. During that period, urban areas were places agriculturalists gathered for trade and defence. While the remote villages (rural areas), outside the towns, were strictly farmland and farm settlements. Hence, colonialism only gave a fillip to the dichotomy between rural and urban areas in Nigeria through the introduction of regionalism in 1946. In the sense that, regionalism opened the way for the rapid urbanisation and development of the capitals of the dominant majority ethnic groups in the west, east and north, while the domain of the minority ethnic groups interlocked and federated with the majority ethnic groups in these regions from 1954, and became the neglected and underdeveloped rural areas.

Historically, the then government initiated economic development in Nigeria in 1946. The TenYear Plan of Development and Welfare Act of 1946 was introduced by the colonial authorities to bridge the rural and urban development gap in Nigeria (Ayo 1988; Okojie 2003; Anyebe 2014). The recourse to planning, according to Anyebe (2014: 20 ), was to enhance the mobilisation of resources to accelerate economic development. Under the 1946 development plan, as the part of the colonial rural development effort, the colonial authorities through the District Officer of Ishan Division, Scallon, identified the capacity of Esanland to contribute to the colonial economy of Nigeria and recommended the establishment of a rice mill in Illushi. More so, under the plan, additional efforts were made to develop the rural economy of Esan when the Sanitary Department sketched out a plan for the construction of a new market in Uromi (National Archive Ibadan 1945). But while the 1946 plan worked to improve the Esan economy for the good of the British metropolis, in the area of provision of social amenities in Esanland, which is of critical importance to the people, it made no progress. Scallon puts it this way,

No progress appears to have been made with the water scheme, an item that should receive priority in Ishan... Although there were surveys and inquiry into the levels, state of pipes, and water level made for the Ubiaja water supply in 1944, nothing came out of it (NAI 1945).

Understandably, Ayo (1988) points out that the thrust of the Ten Year Development and Welfare Plan was to promote Nigeria's transportation, communication and agricultural development (by increasing cocoa, palm products, cotton, groundnut, and timber production in the country), which benefit the British more than the indigenous people. A total of $£ 110$ million was budgeted to fund the

J Economics, 11(1-2): 1-16 (2020) 
project from April 1, 1946 to March 31, 1956. However, while the Ten-Year plan was undeniably the first official economic development planning effort in Nigeria, it lacked the patriotic zeal and national character needed to harmonise and equalise development in Nigeria's urban and rural economies. Consequently, the then government introduced federalism in 1954, and the central government and each of the respective regional government launched their own individual FiveYear Development Plan from 1955-1960. It replaced the Ten-Year plan and entrenched the culture of staggered and uneven development in Nigeria. However, there was no feasible development recorded in any of the regions during the period, which made Ayo describe the Five-Year plan as a mere list of projects hastily prepared without consideration and regard for the needs of the people (Ayo 1988: 1-2).

It is against this backdrop that it is safe to argue that real national economic development planning began in Nigeria with the First and Second National Economic Development Plans from 1962 to 1974. According to Ekundare (1973: 388), the economics of post-independence Nigeria was dominated by planning because Nigeria's civilian leadership saw economic planning as the magic wand to change the economy portrait of the nation. Hence, the African Development Bank (A.D.B.) (2013) reports that post-colonial economic development plans in Nigeria were geared towards eliminating the problem of inequality and inclusion that characterised the Nigerian economy. It is in line with this objective that this paper will examine the extent to which the First and Second Economic Development Plans achieved developmental parity and economic inclusion and integration between Nigeria's mainframe urban economy and the rural economy of Esanland.

The First National Development Plan (FNPP) was initiated in June 1962-1968. The plan covered a six-year period of Nigeria's economic development planning, during which the leadership of the nation sought to achieve a four percent growth rate in the Nigerian economy by investing fifteen percent of Nigeria's Gross Domestic Product (G.D.P.), and by increasing per capita consumption by one percent (Ekundare 1973). The plan is the first proper national development plan in the Nigerian federation because, under it, all the regional governments of Nigeria recognised and accepted the core objectives of the First Development Plan. Iheanacho (2014: 51-52) identified the common objectives pursued by the Nigerian federal and regional governments as:

1. To promote equal distribution of national income.

2. To speed up the rate of economic growth.

3. To generate savings for investment and reduce dependence on external capital for development.

4. To raise money for human resources development.

5. To increase the standard of living of the masses, particularly in respect of food, clothing, housing and health.

6. To increase the infrastructural development of Nigeria.

Therefore, the FNDP was launched to pave the way for Nigeria's economic growth and development by prioritising Nigeria's agricultural and industrial development, and by providing training for the high and intermediate workforce of the country (Mordi 2000). But Chete et al. (2014) argue that what the FNDP did to drive Nigeria's economic development effort was to promote Import-Substitution Industrialisation (ISI) as a cost/benefit means of mobilising and deploying financial resources among contending projects. The government budgeted $\$ 2,132$ million for the plan. Out of which the public sector contributed $¥ 1,352.3$ million, while the private sector contributed $\$ 780$ million (Ayo 1988). Providing insight into the depth of private sector partnership in the FNDP, Ekundare (1973: 388) explains that,

The government wanted Nigerian businessmen to control a greater portion of the Nigerian economy...through the accelerated training of businessmen, the provision of advisory and training services, and the improved flow of capital and technical and market information.

However, a breakdown of the $\$ 1,352.3$ million public sector fund allotted to finance the plan shows that fourteen percent of the money was allocated to primary production, thirteen percent to trade and industry, 15.1 percent to electricity, 21.3 percent to transport, and 10.3 percent to education (Ayo 1988). The lopsided execution of the FNDP resulted in urban development with the construction of the Port Harcourt Oil Refinery, the Nigerian Security and Minting Plant,

J Economics, 11(1-2): 1-16 (2020) 
the Jebba Paper Mill, the Bacita Sugar Mill, the Niger Dam, the Niger Bridge, and some trunk roads in strategic urban centres across Nigeria. However, while the performance scorecard of the FNDP, in terms of its contribution to urban development is impressive, yet rural development never received any allocation, particularly the development of Esanland.

During the FNDP planning period, Esanland experienced a political transformation with no economic value. From being a part of the minorities in the Western region, the region through the territorial restructuring of Nigeria (state creation) transformed into one of the minority's mini-states in the newly created mid-west region in 1963. Esanland did not reap any significant economic dividend from the FNDP because of the cankerous politics of ethnicity and regionalism that was rife in Nigerian First's Republic. This accounts for the marginalisation of minority groups like Esan and their exclusion from the government's developmental programmes and projects. Hence, despite the evident capacity of Esanland to host a modern textile industry if the government had invested in the Esan cloth industry, the industry was ignored and allowed to die. To host a modern rice industry if the FNDP had supported the Ekpoma and Ilushi Rice Milling businesses, but the central implementing authority also ignored this potential of Esanland. Consequently, while the FNDP during the period was able to grow the urban economy of Nigeria by five percent per annum (Ayo 1988), the economy of Esanland like other rural economies suffered neglect, deterioration and displacement.

In 1970, the Second National Development Plan (SNDP) was launch to replace the FNDP, at the end of the Nigerian Civil War. The SNDP was a Four-Year national economic development plan (1970-1974). According to Ayo (1988: 7), while the aim of the projects was basically to reconstruct and reboot Nigeria's degraded economy damaged by the Nigerian Civil War of 1967-1970, its specific objectives were to establish post-war Nigeria securely as:

1. A united, strong and self-reliant nation.

2. A great and dynamic economy.

3. A just and egalitarian society.

4. A land of bright and full opportunities for all citizens.

5. A free and democratic society.

From the (iii) and (iv) objectives of the SNDP, it is clear that the plan was partly initiated to address the economic segregation that marred the FNDP and fostered uneven execution of developmental projects and programmes in Nigeria. Therefore, the plan sought to bridge the historic economic gulf between the urban and rural economies in Nigeria sustained by the FNDP through rural-urban economic integration. Ayo (1988: 10) explains it this way,

This plan differed from its predecessors in several distinct ways. Because being much bigger in size and more diversified in its project composition, it was...the first truly national and fully integrated plan, which viewed the economy as an organic unit, and the (then) twelve states were fully integrated into the national development plan.

Towards this end, Chete et al. (2014) wrote that the SNDP attempted to reverse and reposition the ISI strategy of the FNDP by placing more emphasis on the upgrading of local production across Nigeria, and create a direct link between industrialisation, agriculture, transport, mining, and quarrying. Consequently, the SNDP brought about a remarkable policy shift in Nigeria's economic development drive. Development efforts transited from the hitherto private sectorled industrialisation to the direct public sector industrial planning and implementation for development. This policy shift geared towards encouraging rural development, further became evident in the funding of the plan. Out of the total capital of $¥ 4.9$ billion budgeted for the project, the proposed public sector investment was $\$ 3.3$ billion, and private sector investment in the plan was $\$ 1.6$ billion (Ayo 1988). However, since the cardinal aim of the project was to rebuild Nigeria's infrastructure destroyed during the Nigeria Civil War, the breakdown of the financial allocation of the plan shows that transport received 23.1 percent of the total budgeted capital, and the bulk of the money came from the oil boom (Chete et al. 2014). Hence, funding was not a problem for the SNDP. The project was supposed to increase the Nigerian economy at an average of 6.3 percent per annum, but at the end of the planning year in 1974-1975 it achieved an average growth rate of eleven percent per annum (Ayo 1988).

Like the FNDP, the SNDP failed to achieve the much-desired rural economic development and rural-urban economic integration in Nigeria due to the politics of oil, and the emergence of oil and gas as the new cornerstone of the Nigerian

J Economics, 11(1-2): 1-16 (2020) 
economy. Under the SNDP, oil emerged as Nigeria's leading foreign exchange (and income) earner and economic lifeline of the nation. It downplayed the relevance and capacity of non-oil producing rural economies to contribute to the economic development of the modern Nigerian economy. It is in this circumstance that Esanland, like other rural communities, was relegated to the background in the implementation of the SNDP developmental projects and programmes. It suffices to state here that during the period, the politics of oil successfully dethroned the politics of ethnicity and regionalism to become the primary causation of Esan's economic neglect. The quick revenue guaranteed by oil and gas turned the attention of the government away from agriculture and indigenous industrialisation. More so, being a non-oil producing region, Esanland gained little from Nigeria's National Income (NI) or oil wealth often referred to as the national cake, which was inequitably shared based on the principle of derivation in favour of oil-producing areas. Thus, the centrality of oil and gas to the success of the SNDP ensured that agricultural development, that is, the cultivation of cocoa, palm produce, and rubber in Esan declined, due to the shift of attention of Nigeria's leadership and the demand of the global market from cash crops to crude oil.

\section{Esanland and the Third and Fourth National Development Planning, 1975-1985}

By 1975, the status quo ante of the Nigerian economy had changed significantly. It had metamorphosed fully into an oil-dependent economy. Hence, at the end of the SNDP in 1974, the Third National Development Plan (TNDP) of 1975-1980 was initiated to drive the economic development effort of Nigeria along the lines of her newfound status. The TNDP aimed at directing and coordinating, and maximising Nigeria's oil economy to increase and channel her foreign exchange earnings from crude oil export to national economic development efforts to, of course, make up for the deficiencies of the SNDP of 1970-1974. This economic focus is evident in the TNDP expansion of the SNDP's five (5) fundamental objectives into seven (7) more immediate goals. These Ayo (1988: 10-11) revealed as:
1. To increase per capita income.

2. To promote more even distribution of income.

3. To reduce the level of unemployment.

4. To increase the supply of high-level workforce.

5. To diversify Nigeria's economy.

6. To promote balanced development.

7. To encourage the indigenisation of economic activities in Nigeria.

Like the SNDP, the availability of money to fund the TNDP was not a problem because during the planning period Nigeria had excess cash as a result of the oil boom. During the period, Nigeria's oil production reached a record level of 2.3 million barrels per day by March 1975, with an increase in the international price of oil from USD 3.56 in 1973 to USD 14.69 per barrel. Consequently, from the initial $\$ 30$ billion budgeted for the execution of the plan, the money was later revised to $\$ 43.3$ billion (Ayo 1988). Okojie (2003) observed that the overall economic development strategy of the TNDP was based on the full exploitation of the petroleum sector; and the utilisation of the revenue from oil to develop the production sector of the Nigerian economy. Hence, it can be argued that the plan officially displaced agriculture as the driver of Nigeria's industrialisation efforts. It enthroned oil in its place as the pivot on which the overall economic growth and development efforts of the modern Nigerian economy revolves.

To this end, Chete et al. (2014) maintained that the TNDP placed increased emphasis on public sector investment in industrialisation to grow the economy of Nigeria. The government controlled the oil sector. Because the plan provided an immense opportunity for the public sector to drive the economic growth and development efforts of Nigeria. Therefore, Okojie (2003: 360) revealed that the public sector contributed 80.8 percent of the revenue needed to run the plan, while the private sector financial contribution to the project was a mere 19.2 percent of the total budgeted sum (that is, $\$ 10.3$ billion out of $\$ 53.6$ billion). However, despite its huge budget, the performance scorecard of the TNDP shows that it failed to bridge the economic development gap between rural and urban economies and by extension failed in its goal of changing Nigeria's status as an underdeveloped economy.

Consequently, Esanland under the TNDP experienced progressive economic deterioration.

J Economics, 11(1-2): 1-16 (2020) 
Indeed, under the plan, the building and construction sector of the Nigerian economy flourished, with new infrastructures and building projects springing up across the country. But these building and construction works were mainly white elephant projects pursued by the government in urban areas. However, infrastructure was left to decay in Esan. Esan roads constructed by the British experienced neglect, and were not rehabilitated. The lack of infrastructural development in the region in the third planning period is as a result of the neglect of Esanland in implementation programmes of the TNDP. Despite its huge funding, the plan did not achieve its goals in all nooks and crannies of Nigeria. Nor did the plan promote balanced and even development, nor even distribution of income. Hence, in addition to its infrastructural deficit, Esanland continued to suffer a shortage of social amenities, especially pipe-borne water. Urban development received a further boost under the TNDP, while rural communities languished in poverty and hardship. For example, the Nigerian leadership built a new Federal Capital for the nation in Abuja (Okojie 2003), while Esan and other rural areas shrunk economically because of lack of investment and government presence in the region. Therefore, it is without a doubt that the government channelled the bulk of Nigeria's oil revenue into building roads, stadiums, bridges, new towns and cities to the detriment of rural development. Further, expansion of urban areas and infrastructures under the TNDP negatively affected the demography and labour force of Esanland by fuelling massive rural-urban migration of Esan youths in search of greener pasture in 'Big Cities'.

More so, Nigeria's increased foreign exchange earnings during the period conversely influenced the nation's accelerated taste and penchant for finished foreign goods. During the third planning period, there was so much money in Nigeria that the problem was how to spend it. This explains the high investment of the Nigerian elites in consumption and ostentatious lifestyles; and reckless spending of government such as the Udoji award. Under these circumstances, in Esan, industrial production suffered, as the demand for locally made goods declined. Simply put, under the TNDP, Nigeria found it comparatively advantageous to import than to produce. Resultantly, despite well-meaning programmes such as the National Accelerated Food
Production Programme (NAFPP) initiated under the TNDP, in Esan, the wheels of agricultural and industrial food production retrogressed because the demand for foreign products eclipsed demand for local products. Such as Esan cloth, locally made pomade, cooking oil and soaps. However, the original plan was to fast-track agricultural research in food and cash crops, and also, research development in livestock production/electrification of rural areas such as Esanland, as observed by Ibietan and Ekhosuehi (2013). In the area of increasing social welfare and amenities such as water supply, health, and housing in Esan, which Okojie (2003) claimed it achieved in Nigeria, the TNDP did just the exact opposite in Esanland.

The Fourth National Development Plan (FNDP) of 1981-1985 was designed to be a four-year economic development plan. The plan was initiated to make up for the shortfall of the TNDP in achieving comprehensive rural-urban economic integration and economic growth and development in Nigeria. Okojie (2003) argues that the TNDP could not attain optimal performance during its planning period because of the decline in oil revenue in the 19751976 fiscal year, and this necessitated the review of the plan. Okojie (2003: 360) explains it this way,

The performance ratio of the plan (TNDP) was 67.9 percent. Because the economy had no growth momentum of its own (after the fall of oil price), the growth of the GDP fell sharply from 7.55 percent in 1977 to 1.11 percent in 1978 as a result of the oil price shock in 1978.

Understandably, Chete et al. (2014) argue that the FNDP came into existence during a period of global economic recession, which is a period of economic change in Nigeria. Njoku (2001) and Emordi (2019) insist that this was best described as the oil doom era when the bubble of the oil boom burst. This period was characterised by a balance of payment disequilibrium and high rate of unemployment in the Nigerian economy. Thus, it is against this backdrop that FNDP was launched to help restructure Nigeria's imbalanced economy. The specific objectives of the Fourth National Economic Development Plan are, according to Iheanacho (2014: 54):

1. To increase the real income of the average Nigerian citizen.

2. To promote even distribution of income among individuals and socio-economic groups. 
3. To reduce the level of unemployment and underemployment in Nigeria.

4. To increase the supply of skilled workforce.

5. To reduce Nigeria's economic dependency to a narrow range of activities.

6. To increase citizen's participation in the ownership and management of productive enterprises.

7. To foster greater self-reliance, that is, increased dependence on local content or resources in production.

8. To promote Nigeria's technological development.

9. To increase productivity in the Nigerian economy.

10. To promote a new national orientation conducive for achieving greater discipline, better attitude to work, and a cleaner environment in Nigeria.

Okojie (2003) asserts that in terms of its objectives, the plan was sufficiently similar to its predecessors, that is, with heavy reliance on internal resources for funding. The government budgeted $\$ 82.2$ billion for the execution of FNDP. Out of this amount, the public sector contributes $\$ 70.5$ billion (the Federal government was to contribute $\$ 42.2$ billion and the State government 28 billion), while the private sector contributes $\$ 11.74$ billion. However, the continuous fall in the price of oil seriously affected Nigeria's national income during the period, and this reduced her capacity to fund the plan effectively. According to Okojie (2003: 361), Nigeria's "oil export earnings dropped from about USD 22.4 billion in 1980 to USD 16.7 billion in 1981 and then to USD 14.3 billion in $1982 \ldots$. This made it difficult for the FNDP to accomplish any of its proposed projects, particularly in the aspect of housing, free education and health care delivery. Hence, Esanland, like other rural areas in the country, bore most of the brunt of the failure of FNDP in terms of socio-economic underdevelopment.

Socio-economic conditions in Esan worsened following the collapse of the fourth plan. While it is true that suffering was widespread in Nigeria during this period, it is more accurate to maintain that in rural areas such as Esan where the poverty ratio was already high and the economy retarded, the suffering of the people was untold. Esan people never benefit in terms of infrastructural development through the provision of basic social amenities. Government's investment of oil revenue in industrialisation did not benefit the region as well. Consequently, the people paid a high price like other less privileged minorities for the economic mistakes and mismanagement of Nigeria by political elites under FNDP. However, the Bendel state government's direct investment in Esanland in 1981 resulted in the establishment of the Bendel State University (now Ambrose Alli University) in Ekpoma. The institution boosted trade in Ekpoma and provided employment and job opportunities to the people that could hardly go round. But as a stopgap measure to contain the hardship in Nigeria at the Federal level, the government resorted to borrowing from the International Monetary Fund (IMF), which now recommended the adoption of a Structural Adjustment Programme (SAP) in Nigeria to help readjust, correct, and revamp the low economy of the country. This was believed would end the hardship of rural dwellers in Esan and elsewhere by instigating rural development across the nation.

\section{Esanland and the Fifth National Development Planning, 1988-1992}

Based on structural adjustment economic guidelines the IMF gave to Nigeria in 1986, the Nigerian Institute of Social and Economic Research (NISER) and the Federal Ministry of Nation Planning (FMNP) initiated the Fifth National Development Plan (FthNDP) as Nigeria's economic development blueprint for the period 1988-1992. The fifth economic development plan served as the national policy framework for the operationalisation of SAP in Nigeria. Hence, under the objectives of SAP, Okojie (2003: 362-363) observed that the FthNDP sought to achieve the following:

1. The diversification of Nigeria's economy away from its mono-cultural dependence on the oil sector.

2. The revitalisation of the agricultural industry with a view of achieving self-sufficiency in food production through the rural integrated development programme.

3. Domestic production of raw materials for local initiatives to reduce the import content of locally manufactured goods.

4. The promotion of employment opportunities to arrest deteriorating mass unemployment. 
During this period of planning Nigeria's economic growth and development, the Federal government of Nigeria retained, incorporated and continued some of the laudable and complementary programmes of past administrations, especially policies and programmes directly in sync with objectives of the fifth plan. These programmes were critical to the actualisation of goals (ii) and (iv) of the FthNDP that seek to promote rural development, increase employment opportunities in rural areas, and the subsequent integration of rural economies with the urban economies. These extant programmes, according to Njoku (2001) and Okojie (2003), include the Directorate for Food, Roads, and Rural Infrastructure (DFRRI), Better Life for Rural Women Programme (BLRWP), and National Directorate of Employment (NDE). Njoku (2001: 219-220) writes that the primary aim of the DFFRI programme in Nigeria was the eradication of rural poverty and diseases through the provision of rural infrastructure and other essential amenities such as rural feeder roads, potable water, and electricity among other vitals. While the BLRWP was initiated by Maryam Babangida to complement the efforts of the Federal government in promoting rural development by trying to stimulate rural women across Nigeria to achieve a higher standard of living through political and economic participation, and through hygiene and family planning education.

It is against this backdrop that this paper interrogates the impact of the Fifth National Development Plan on the economic development of Esanland, and the economic fortunes of the Esan people. During this planning period, the government federalised Esanland into Nigeria's south-south geopolitical zone under Edo state created in 1991 from former Bendel State that was split into Edo and Delta States. Politically the people of Esanland were directly affected by the leadership of Nigeria during the period of the fifth plan. Still, on the socio-economic sphere, the people did not feel the impact of the Federal government. By 1991, the economy of Esanland was in no way plan better than what it was before the fifth plans. Industrial and infrastructural development in the region was in a state of near-total neglect. The continued dilapidation of existing Esan roads during the planning period demonstrates that the DFRRI objectives of the government were not correctly carried out in Esanland. The regional implementation of policies such as DFRRI and others, on which development planning was anchored, helped to cripple the fifth plan. More so, the failure to industrialise Esanland increased the rate of unemployment and poverty in the region. The brunt of the industrial underdevelopment of Esan was borne more by Esan women because of the rate of illiteracy among Esan women and the decline of industrial activities such as cloth-making hitherto dominated by Esan women. Therefore, the prevalence of poverty among Esan women during the planning period proves that the "Better Life for Rural Women Programme" was of no benefit to Esan folks under the FthNDP program.

Like the previous plans, there was nothing wrong with the FthNDP in terms of its objectives, but its implementation was the problem. Its underperformance in Esanland was as a result of cankerous centrifugal forces, like politics of ethnicity and economic dysfunctionalism, which were plaguing the Nigerian political system. These provide a political economy explanation of why the thirty-five Esan communities have continued to suffer neglect. Standard of living in the region is very poor, as the Esan people still do not have access to portable pipe-borne drinking water. Adapting to this harsh socioeconomic reality, the Esan people have now become heavily reliant on rainfall for drinking water, and water for other domestic activities such as cooking and washing of clothes, and farm use. However, the water scarcity in Esanland has created new economic opportunities for a few privileged individuals in the region. Well to do Esans, who possess the economic wherewithal to drill boreholes, have taken advantage of the water situation to emerge as big-time water merchants and pure water (sachet water) entrepreneurs in Esanland. These business vendors exploit the people more during the dry season because of the monopoly they enjoy in the water market. They charge a minimum of $\$ 50$ per 20 -litre gallon and \$200 for a bag of pure water.

From the preceding, it is safe to argue that the fifth development plan, like its predecessors, treated rural development in Nigeria with ignominy. The neglect of rural development in Nigeria has continued to fuel rural-urban migration in Esan instead of curbing it, which DFRRI under the fifth plan sought to achieve. More so, the FthNDP purports to revitalise the agricultural sector and increased food sufficiency in Nigeria through rural

J Economics, 11(1-2): 1-16 (2020) 
agrarian development and integration with the urban economy. However, by the time the government's economic development planning period elapsed in 1992, the rural economy of Esanland was marred by food shortage due to mobility of labour to urban economies for green pasture. The Esan economy emerged from it severely disconnected from the mainframe urban national economy because of deficiency of government investment in the rural area. Roads, railways, economic institutions such as banks, modern markets needed to stimulate the economy of Esanland were poorly provided in Esanland. These are the teething economy problems Esanland carried over into Nigeria's new phase of economic development planning. It was the anticipation of Nigerians everywhere that perspective planning would trigger rural development, which fixed-term planning failed to do.

The period of perspective economic development planning was a watershed in the economic development history of Nigeria. It was a period of marked departure from fixed medium-term planning to the era of rolling plans. Perspective planning was a futuristic economic development targeting. On November 27, 1996, it was entrenched in Nigeria when General Sani Abacha inaugurated the Vision 2010 Committee. The Committee initiated the Vision 2010 that sought to make Nigeria economically prosperous and socio-politically stable before the year 2010 (Okojie 2003). It was replaced by the Millennium Development Goals (MDGs) of 2015, which sought to eradicate extreme poverty and other indicators of underdevelopment in rural areas, and eventually by the Vision 20:2020 conceived to transform Nigeria into one of the top 20 economies in the world by 2020 (Eneh 2011). It is instructive to note that this perspective plans like other development plans before since 1970 were all tied to the price of oil and gas the mainstay of the Nigerian economy. But like the other fixed-term plans earlier, they have not been able to materialise into real economic development in Esanland (Eserkhaigbe 2019; Amedu 2019; Onoleme 2019). This paper observes that the obstacle to the realisation of the objectives of Nigeria's futuristic economic development visions is mostly the failure to develop and integrate all rural economies in the country into the national mainframe economy of the country. Put simply, the plans and visions were not dispassionately implemented by government in Esanland and other rural areas in Nigeria.

\section{CONCLUSION}

This paper is a development economics review of Esanland in the context of modern Nigeria's development planning. It finds that the neglect of rural development is the bane of Nigeria's economic underdevelopment. It maintained that development planning has failed to yield the desired result in Nigeria because of the massive politicisation of economic decisions. It argued that planning in Nigeria since 1960 has been well-articulated and national in outlook, but not in implementation. The implementation of development plans had been highly lopsided in favour of urban areas. This paper maintained that this is fundamentally responsible for the economic underdevelopment of Esanland. The rural economy has continued to suffer economic neglect and under-exploitation of its economic potentials because of ethnic politics. Political and regional implementation of plans had denied Esanland and other rural areas social amenities, infrastructural and industrial development. More so, the oil and gas configuration of Nigeria's economy, this paper finds, is contributory to the disconnection of all non-oil producing rural economies from the Nigerian economy. Therefore, the report contends that development planning does not atuomatically lead to economic development. However, comprehensive planning plus dispassionate implementation of plans based on economic needs assessment, minus resources diffusionism do.

\section{RECOMMENDATIONS}

Implicit in the discussion of this paper, is the contention that the economic development of the modern Nigerian economy rests squarely on rural economic development and integration. To achieve this economic synergy between rural and urban economies in Nigeria, this paper argues that development planning should be predicated on the result of comprehensive surveys carried out to assess the economic needs and potentials of all regions in the country. More so, development plans, visions, policies and programmes need to be nationally and patriotically implemented. The paper also recommends that for economic development to be fast-tracked in Nigeria, economic decisions in the country such as the location of industries, construction of economic infrastructures and provision of

J Economics, 11(1-2): 1-16 (2020) 
social amenities must be economically determined. They should not be over-concentrated in one region but evenly distributed across the country. They must be seen as economic development imperatives, not as dividends of democracy provided as a political reward for partisan politics and loyalty.

Further, the paper recommends that the economic capacities of rural areas, and their historical economic antecedent should be carefully taken into consideration by the Nigerian government as its budgeting and investment guide. More so, since Nigeria's adumbrated federalism had rendered the top-bottom and bottom-top economic development strategies unworkable in the country, the report argues that the most viable strategy for closing the economic development gulf between rural and urban economies in Nigeria is the simultaneous economic development strategy. It can be guaranteed by political restructuring geared towards empowering the 36 states of Nigeria to control and exploit their resources for their individual economic growth and development. If this is done, states and regions in Nigeria will develop at their own pace, according to their environment, needs and resources. It will accelerate rural economic growth and give impetus to rural-urban integration in Nigeria.

\section{REFERENCES}

Acemoglu D, Robinson JA 2013. Why Nations Fail: The Origins of Power, Prosperity, and Poverty. London: Profile Books Ltd.

Adedeji A 1981. General background to indigenisation: The economic dependence of Africa. In: Adebayo Adedeji (Ed.): Indigenisation of African Economies. London: Hutchinson University Library for Africa, P. 21.

Admos OC, Hulme D, Munro L 2019. The new national development planning and global development goals: Processes and partnership. World Development, 120: 76-79.

African Development Bank Summary Report 2013. An Infrastructure Action Plan for Nigeria: Closing Infrastructure Gap and Accelerating Economic Transformation. Tunis Belvedere: A.F.D. Group.

Akinbowale EO 2018. National development plan, human capital investment and economic growth in Nigeria: A survey of literature. International Journal of Academic Management Science Research, 2(5): 27-30.

Amedu E 2019. Personal Interview. 83 years, Retired Civil Servant/Artisan, 1 July, 2019.

Anyebe AA 2014. Federalism and national development planning in Nigeria. Public Policy and Administration Review, 2(4): 19.

Awojobi NO 2014. Sustainable rural development in Nigeria within the context of the millennium development goals. International Journal of Contemporary Applied Sciences, 1(1): 64.
Awopegba PO 2003. Human resources, high-level manpower and the development of the Nigerian economy. In: MA Iyoha, CO Itsede (Eds.): Nigerian Economy: Structure, Growth and Development. Benin City: Mindex Publishing, P. iii.

Ayo EA 1988. Development Planning in Nigeria. Ibadan: University Press Ltd.

Basumatary M 1993. Challenges and strategies of rural development in Assam. International Journal of Advanced Research, 4(10): 1842.

Chete LN, Adeoti JO, Adeyinka FM et al. 2014. Industrial Development and Growth in Nigeria: Lesson and Challenges. Ibadan: Nigerian Institute of Social Science and Economic Research (NISER).

Chukwuemeka E, Ugwuanyi BI, Amobi DSC 2013. Enhancing rural development in Nigeria periscoping the impediment and exploring the imperative actions. International Journal of Management Sciences and Business Research, 2(7): 55-60.

Dibua JI 2013. Development and Diffusionism: Looking Beyond Neopatrimonialism in Nigeria, 1962-1985. New York: Palgrave Macmillan.

Donaldson P 1971. Worlds Apart: The Economic Gulf between Nations. Middlesex: Penguin Books Ltd., 1971.

Ekundare RO 1973. An Economic History of Nigeria 18601960. London: Methuen \& Co. Ltd.

Emordi C 2019. Personal Interview. 60 years, Professor of History, Ekpoma, 23 July, 2019.

Eneh OC 2011. Nigeria's Vision 20:2020: Issues, Challenges and Implication for Development Management, Asian Journal of Rural Development, 1(1): 21-22.

Eserkhaigbe E 2019. Personal Interview. 61 years, Retired Teacher/Trader, Ekpoma, 24 June, 2019.

Ezeife E 1981. Nigeria. In: Adebayo Adedeji (Ed.): Indigenisation of African Economies. London: Hutchinson University Library for Africa, P. 182.

Hodder BW 1972. Economic Development in the Tropic. London: Methuen \& Co. Ltd.

Hopkins AG 1973. An Economic History of West Africa. New York: Longman Group Ltd.

Huertas-Ramos JD 2017. Development planning: From the concept to the technique. Administration Desarro, 47(2): 26-27.

Ibietan J, Ekhosuehi O 2013. Trends in development planning in Nigeria, 1962-2012. Journal of Sustainable Development in Africa, 15(4): 302.

Iheanacho EN 2014. National development planning in Nigeria: An endless search for appropriate development strategy. International Journal of Economic Development Research and Investment, 5(2): 51-52.

Iyoha MA, 2003. An Overview of Leading Issues in the Structure and Development of Nigerian Economy since 1960. In: MA Iyoha, CO Itsede (Eds.): Nigerian Economy: Structure, Growth and Development. Benin City: Mindex Publishing, pp. 3-4.

Jhingan ML 1997. The Economic of Development and Planning. $39^{\text {th }}$ Edition. Delhi: Vrinda Publications Ltd.

Kolawole BO, Ojapinwa TV 2013. Economic planning models for development: The relevance for a developing economy. International Journal of Humanities and Social Science, 3(16): 208

Lloyd PC 1974. Power and Independence: Urban Africans' Perception of Social Inequality. London and Boston: Routledge \& Kegan Paul.

J Economics, 11(1-2): 1-16 (2020) 
Ministry of Budget and National Planning Nigeria 2017. Economic Recovery and Growth Plan, 2017-2020. Abuja: Ministry of Budget and Planning.

Mordi CNO, Englama A, Adebusuyi BS (Eds.) 2000. The Changing Structure of Nigerian Economy. Central Bank of Nigeria.

National Archives Ibadan 1945. Annual Report on Ishan Division 1945. I.D. 737, Vol. IV, N.A.I.

National Bureau of Statistics (NBS), 2019 Poverty and Inequality: Executive Summary, May 2020

National Bureau of Statistics, Nigeria Poverty Profile 2010, January 2012

National Planning Commission 2009. Nigeria's Vision 20:2020: Economic Transformation Blueprint. December.

Njoku ON 2001. The Economic History of Nigeria in the $19^{\text {th }}$ and $20^{\text {th }}$ Centuries. Enugu: Magnet Business Enterprises (Publishing Division).

Okojie CE 2003. Development planning in Nigeria since independence. In: MA Iyoha, CO Itsede (Eds.): Nigerian Economy: Structure, Growth and Development. Benin City: Mindex Publishing, P. 355.

Onoleme O 2019. Personal Interview. 85 years, Farmer,
Ekpoma, 25 June, 2019.

Rodney W 1972. How Europe Underdeveloped Africa. London: Bogle-L'Ouverture.

Smith A 2003. The Wealth of Nations. New York: Bantam Dell. Todaro MP, Smith SC 2011. Economic Development. $11^{\text {th }}$ Edition. Harlow: Pearson Education Ltd.

Uche E 2019. Development plans and policies in Nigeria: Observed impediments and practical best alternatives. International Journal of Research and Innovation, VI(VII): 27.

United Nations 2020. World Economic Situation and Prospects. New York: United Nations.

Uwubanmwen AE 2003. Development of Industry and Manufacturing. In: MA Iyoha, CO Itsede (Eds.): Nigerian Economy: Structure, Growth and Development. Benin City: Mindex Publishing, P. 83.

Welsh Government 2013. Planning for Economic Development: Towards a New Technical Note. London: Peter Brett Associates, L.L.P. and Asbri Planning Ltd.

Paper received for publication in May, 2020

Paper accepted for publication in September, 2020

J Economics, 11(1-2): 1-16 (2020) 